

\title{
Die rol van Christelike waardes en opvoeding in Verkeersveiligheidsopvoeding
}

\author{
M. Scott en O. Marx \\ Nagraadse Skool vir Opvoedkunde \\ Potchefstroomse Universiteit vir CHO \\ POTCHEFSTROOM \\ E-pos:dopms@puknet puk.ac za
}

\begin{abstract}
The role of Christian values and education in Traftic Safety Education

Traffic safety is one of the more important issues in South Africa today, since traffic accidents cause thousands of unnecessary deaths each year, particularly among the youth. The key variable of traffic safety is to be found in principled education emphasizing religious and life values. A child need to learn that life, also his/her own, is sacred to God and must be safeguarded by following traffic safety rules and regulations. Since traffic safety is dependent on, inter alia, attitudes and religious-cultural values, children must be taught positive attitudes at home and at school. This point of departure implies that teachers need to have positive attitudes towards Traffic Safety Education, which, in turn, implies Traffic Safety Education as a prerequisite for teacher education.
\end{abstract}

\section{Inleiding}

Suid-Afrika, soos talle ander lande, beleef heelwat tydgebonde sosiale vraagstukke wat tot sterftes lei - vraagstukke soos moord, gewelddadige verkragting en diefstal, ernstige depressie, selfmoord en VIGS (Atkinson et al., 1993: $113,638-639)$. Swak verkeersveiligheid is 'n verdere sosiale vraagstuk wat reeds vir etlike jare, maar veral vandag, een van die grootste enkele oorsake van sterfgevalle onder alle ouderdomsgroepe in Suid-Afrika is (Sentrale Statistiekdiens, 1994:295), soos ook in Amerika (Martinez et al., 1993), Kanada (Cooper et al., 1994) en Swede (Gregersen \& Bjurulf, 1996). Onderliggend aan die meeste sosiale vraagstukke is, onder andere, negatiewe houdings (De Bruyn, 1992:7) wat, volgens Atkinson et al. (1993:730) enersyds 'n sekere tipe selfbeeld weerspieël, en andersyds die uitdrukking is van die spesifieke waardes wat jeens 
'n saak gehuldig word. Hierdie waardes word uiters moeilik verander as hulle eers vasgelê is. Hierdie artikel fokus op verkeersveiligheid as sosiale vraagstuk in Suid-Afrika, en wel op die rol wat opvoeding kan speel in die vaslegging en vroeë verandering van waardes en houdings daarteenoor. Die fokus van die artikel beteken geensins dat slegs opvoeding verkeersveiligheid kan beïnvloed nie; ander faktore, soos beter onderhoud van paaie, effektiewer verkeersregulering en wetgewing is inderdaad ook nodig.

Waardes dui op daardie kwaliteite en voorwaardes wat mense motiveer om op sekere wyses op te tree en ook ander daartoe aan te spoor, omdat sulke optrede tot almal se voordeel is (Fowler et al., 1990:52). Waardes kom nie plotseling tot stand nie, maar is die resultaat van die interaksie tussen opvoeding en persoonlike ontwikkeling, en veral kognitiewe, sedelike en sosiale ontwikkeling (Woolfolk, 1995:80-85). Volgens Fowler et al. (1990:52) is waardes wat met opvoeding verband hou "grounded in life values developed in the context of a world view at the heart of which is a religious commitment of one kind or another". Die waarde van 'n saak word bepaal deur te vra na hoe belangrik of nuttig die saak vir 'n individu is, en hierdie antwoord word ten diepste bepaal deur die religieuse gerigtheid van die mens (Scott, 1991:52, 1987:153). Opsommenderwys kan gestel word dat lewensbeskouing die raamwerk vir die interpretering van die waarde van enige lewenservaring vorm en dat hierdie lewensbeskouing en waardesisteem wat met die verloop van tyd onder invloed van opvoeding ontwikkel, baie bestand is teen verandering.

Logies volg dat die regte waardes jeens verkeersveiligheid so vroeg as moontlik deur opvoeding en onderrig ingeskerp moet word indien 'n positiewe houding tydens die adolessente en volwasse jare van die padgebruiker verlang word. Hierdie gevolgtrekking word gestaaf deur navorsing wat bevind het dat opvoeding en onderrig op skool wêreldwyd gesien word as belangrik vir die bevordering van verkeersveiligheid (Gregersen \& Bjurulf, 1996:229; Dreyer, 1986:37). Hierdie tipe onderrig word as noodsaaklik geag aangesien dit reeds sedert die tagtigerjare ' $n$ daling in verkeersongelukke teweeggebring het in die Verenigde State van Amerika, Denemarke, Nederland, Australië en Nieu-Seeland (Martinez et al., 1993; Sheehan \& Schonfeld, 1992).

Dat verkeersveiligheidsopvoeding op skool weinig invloed op padsterftes op Suid-Afrikaanse paaie het, blyk uit die 1994-statistieke vir jaarlikse sterftes onder skoolgaande kinders en jongmense as gevolg van onveilige padgebruik. Die 1994-statistieke bied die volgende gegewens: 4510 voetgangers en 96 fietsryers, 930 motorfiets- en kragfietsryers tussen die ouderdomme van 16 en 24 jaar, en 16005 voertuigbestuurders (18-24 jaar) het in 1994 in padsterftes omgekom (Sentrale Statistiekdiens, 1994:295, 301, 325). Smit en Drinkwater (1989:63) en Taute (1987:2) skryf die swak resultate van programme in verkeersveiligheidsopvoeding deels toe aan die gebrek aan opleiding om sulke programme te beplan 
en aan te bied. Hierdie feit word ondersteun deur die feit dat slegs die Potchefstroomse Universiteit vir CHO tans onderwysstudente verplig om 'n kursus in verkeersveiligheidsopvoeding te volg. Tweedens berus die oorsaak van die ondoeltreffendheid van die programme op die houding wat leerlnge en onderwysers jeens verkeersveiligheid koester en die waardes wat hulle aan sodanige opvoedingsprogramme heg (Gregersen \& Bjurulf, 1996:230; Martinez et al., 1993; Smit, 1990:29). Hierdie bevinding geld egter nie net vir Suid-Afrika nie.

Binne die raamwerk van Kurrikulum 2005 (Die Staatskoerant, 1997), wat die verskillende leerareas vir toekomstige onderwysprogramme bevat, val lewensbeskouing en waardes in die leerarea Lewensoriëntering. Die doel van Lewensoriëntering is om leerders te begelei om só te ontwikkel dat hulle betekenis aan hulle lewe kan gee binne 'n gemeenskap wat aan vinnige verandering onderhewig is. Lewensoriëntering "enhances the practice of positive attitudes, behaviour and skills in the individual and community", en moet die leerder se potensiaal ten opsigte van verskeie fasette van sy/haar menswees bevorder (Kurrikulum 2005, Gespreksdokument Graad I tot IX, 1997:220). Kurrikulum 2005 bied die ideale geleentheid om leerlinge se houdings jeens, onder andere, verkeersveiligheid te verander deur hulle waardestelsels positief te beïnvloed. Bestaande programme moet dus geanaliseer word om die sterk punte en leemtes te identifiseer, en eersgenoemde in nuwe programme in te bou en laasgenoemde te vermy.

In die konteks van Suid-Afrika se verkeersongeluksyfer en die houding van leerlinge en onderwysers jeens Verkeersveiligheidsopvoedingsprogramme, is die volgende vrae baie relevant: Watter programme word tans op sekondêre skoolvlak aangebied in verkeersveiligheid? Watter waarde heg leerlinge en onderwysers aan hierdie programme? Kan hierdie waarde verander word?

Om hierdie vrae te beantwoord, sal eerstens aandag gegee word aan die betekenis van die begrip verkeersveiligheidsopvoeding (vgl. par. 2), en wel vanuit 'n religieus-kulturele perspektief. Tweedens sal gekyk word na wat verkeersveiligheidsopvoedingsprogramme op sekondêre skoolvlak tans behels en watter waarde aan die programme geheg word (vgl. par. 3). Derdens volg die vraag of die aanbieding van sodanige programme in onderwysersopleiding verreken word, omdat sodanige inligting die waarde van die programme kan verhoog (vgl. par. 4).

\section{Verkeersveiligheidsopvoeding: 'n religieus-kulturele perspektief}

Die drie begrippe waanit verkeersveiligheidsopvoeding bestaan (naamlik: verkeer, veiligheid en opvoeding; vgl. par. 2.1), sal eers beskryf word, waarna 
Die rol van Christelike wadrdes en opvoeding in Verkeersvelligheidsopvoeding

die religieus-kulturele begronding (vgl. par. 2.2) van verkeersveiligheidsopvoeding as enkelvoudige begrip sal volg.

\subsection{Begripsomskrywing}

\section{- Verkeer}

Verkeer is deel van die alledaagse lewe waarin hedendaagse mense hulle bevind, aangesien alle mense verkeersdeelnemers word sodra hulle hulle wonings verlaat. Volgens die Verklarende Handwoordeboek van die Afrikaanse Taal (1994:1175) het verkeer ' $n$ tweeledige betekenis: die eerste dui op enige vorm van beweging en die tweede op interaksie. Die interaksie tussen die verkeerselemente bestaan uit die statiese komponent (soos strate en verkeersligte), die dinamiese komponent (soos voertuie) en die verkeersdeelnemer self, met sy/haar unieke eienskappe, soos kennis van verkeersreëls, waarnemingsnelheid en houding of gesindheid (Steyn, 1987:207; Dreyer, 1986:6). Volgens De Bruyn (1992:7) dui houding op verantwoordelikheid en selfbeheersing, wat noodsaaklike voorvereistes is ten einde die ingewikkelde stelle reêls, regulasies en voorskrifte wat die gedrag van die verkeersdeelnemer moet reguleer, te gehoorsaam. Alle mense, maar veral kinders en adolessente, moet bewus gemaak word van die waarde van die reēls en ook bekwaam gemaak word om veilig deel te wees van die verkeer (Steyn, 1987:207).

\section{- Veiligheid}

Veiligheid dui op sekerheid, vryheid van gevaar en gerustheid (HAT, 1994:1156), wat, onder andere, die individu se gevoel van en houding of gesindheid jeens sy of haar eie en die veiligheid van ander insluit. Die eis tot hierdie persoonlike houding word gevind in God se liefdesgebod, wat stel dat ek my naaste moet liefhê soos myself, en wat ook beteken dat ek my naaste geen kwaad mag aandoen nie (De Bruyn, 1993:135). Paulus (Fil. 2:4-5) verwoord die verantwoordelikheid om die regte gesindheid jeens veiligheid te openbaar verder wanneer hy sê: "Julle moenie net elkeen aan sy eie belange dink nie, maar ook aan diè van ander. Dieselfde gesindheid moet in julle wees wat daar ook in Christus Jesus was" (De Bruyn, 1992:8). Veiligheid moet ook geinterpreteer word in die konteks van die verantwoordelikheid wat op die owerheid rus om maatreèls te tref vir die beveiliging van mense (De Bruyn, 1993:134-135; Van der Walt, 1984:16). Hierdie verantwoordelikheid is gebaseer, onder andere, op die vyfde van die Tien Gebooie, wat stel dat God aan owerhede die gesag en bevoegdheid gegee het "om wette te maak en reels neer te lê wat vir 'n ordelike samelewing nodig mag wees en toe te sien dat dit gehoorsaam word (Rom. 13:12, soos aangehaal deur De Bruyn, 1992:8). Dat wette en reèls inderdaad op die ordelike verkeer van mense binne gemeenskappe gerig is, word regskundig onderstreep deur Van Zyl en Van der Vyver (1982, soos aangehaal deur 
Oosthuizen et al., 1994:5). Volgens Du Plessis (1978, soos aangehaal deur Oosthuizen et al., 1994:7) beskerm die reg mense binne 'n bepaalde orde en dui beskerming nie net op die voorkoming van inbreukmaking nie, maar sluit dit ook "geborgenheid en sekuriteit" in. Veiligheid (of geborgenheid) van mense, ook binne die verkeersituasie, is dus 'n Goddelike eis wat lei tot wetlike opdrag, wat die verkeersdeelnemer met verantwoordelikheid en selfbeheersing moet gehoorsaam. Verantwoordelikheid en selfbeheersing (as komponente van houding) berus nie slegs op wetstoepassing as eis nie, maar ook op opvoeding (Eggink, 1990:49).

\section{- Opvoeding}

Van Rensburg et al. (1994:172) definieer opvoeding as "'n doelbewuste, doelgerigte bemoeienis van 'n volwassene met 'n nie-volwassene om hom selfstandig te maak". Die doel van opvoeding is volwassenheid, wat prinsipieel beskryf kan word as die stadium wanneer iemand in staat is tot die selfstandige beoordeling van wat reg of verkeerd is, om vryheid met verantwoordelikheid te hanteer, roepingsbewus te kan handel en ten volle toerekeningsvatbaar te wees (Van Rensburg et al., 1994:260). Indien hierdie prinsipiële volwassenheidsbeeld vir verkeersveiligheidsopvoeding verbesonder word, beteken dit dat die kind en adolessent opgevoed moet word om sedelike oordele te vel oor wat regte en wat verkeerde optrede in terme van verkeersreëls is. Hy of sy moet die reèls met verantwoordelikheid kan gehoorsaam, homself of haarself as toerekenbaar kan beskou ten opsigte van die gevolge van verkeersgedrag, en die beskerming van die eie lewe en die van medepadgebruikers as deel van die Christelike roeping sien. Opvoeding is dus religieus bepaald en hou verband met die mens se lewensbeskouing en waardesisteem.

Garcia (1994:158) gee 'n meer kognitief-humanistiese beskrywing van die doel van opvoeding, naamlik as “... fundamentally, helping students understand, appreciate, and grapple with important ideas while developing a depth of understanding in a wide range of issues". Deur opvoeding (i.c. "education" wat onderrig insluit) moet die nodige akademiese kennis en vaardighede, ook lewensvaardighede ontwikkel word (kyk ook Die Staatskoerant, Junie 1997, vir die doelstellings van Kurrikulum 2005 vir die Leerarea: Lewensoriëntering). Hierdie kennis en lewensvaardighede moet die kind in staat stel om effektiewe menslike verhoudings aan te gaan, krities te dink en sy burgerlike verantwoordelikhede uit te voer (Garcia, 1994:48) - ook in verkeerskonteks want:

The lives of the young people now in school, even more than our own, will be characterized by continuous and dramatic social, economic, and technological change ... They must be able to reflect on and analyse the perplexing array of social and individual problems that are part of modem life (Garcia, 1994:48). 
Die rol van Christelike woardes en opvoeding in Verkeersveiligheidsopvoeding

As 'n tipies menslike aktiwiteit is opvoeding ook kultuurverbonde en kan dit gesien word as 'n bewuste handeling wat die kind regstreeks beünvloed en 'n kultuurbepaalde rigting aan sy of haar ontwikkeling gee (Taute, 1985:14).

\subsection{Die religieus-kulturele basis van verkeersveiligheids- opvoeding}

Die volwassenheidsbeeld waartoe die kind opgevoed word, word bepaal deur die religie van die opvoeder, wat totalitêr, sentraal en integraal is en alle menslike denke en handelinge bepaal (Van der Walt, 1997:30). Al die doelwitte om volwassenheid te bereik word dus geïnterpreteer vanuit 'n lewensopvatting wat sigbaar is in al die doen en late, ook die wyse waarop opgevoed word, of die wyse waarop die pad gebruik word.

Soos religie, speel ook kultuur 'n belangrike rol in die opvoeding van die kind, aangesien religie en kultuur saamgevat is in God se kultuuropdrag aan die mens, naamlik om te vermeerder, die aarde te bewoon, te bewerk, daaroor te heers, maar ook daarvoor te sorg (Van der Walt, 1997:44). God se algemene kultuuropdrag geld vir alle mense en vir alle aspekte van menslike bestaan (Van der Walt, 1997:45). Hierdie algemene kultuuropdrag moet egter gedifferensieerd uitgevoer word binne die konteks van die spesifieke situasie en kennis, taal, sedelike oortuigings, wette, gewoontes en vaardighede wat elke mens as deel van 'n spesifieke kultuurgroep en gemeenskap verwerf het (Postma, 1987:215). Opvoeding, en dus ook verkeersveiligheidsopvoeding as een aspek van die mens se bestaan, kan dus van kultuurgroep tot kultuurgroep verskil, soos ook Christelike opvoeding kan verskil van, byvoorbeeld, naturalistiese opvoeding. Christelike opvoeding sien byvoorbeeld respek en agting vir die owerheid wat verkeersreëls moet afdwing as eis en laat nie die kind aan sy of haar natuurlike instinkte oor nie.

'n Moderne verkeersituasie sonder reëls en regulasies is net so ondenkbaar as 'n samelewing sonder norme of behoorlikheidseise. Die doel van opvoeding, ook in verkeersveiligheid, is volwassenheid waarvan die tipiese beeld religieuskultuurbepaald is. Hierdie volwassenheid word bereik deur middel van opvoeding en onderrig gerig op die verwerwing en ontwikkeling van kennis, vaardighede, waardes, gesindhede en houdings. Die vraag is of bestaande programme in verkeersveiligheid genoemde doel insluit en bereik. 


\section{3. 'n Evaluering van die inhoud van enkele skoolprogramme in verkeersveiligheidsopvoeding op sekondêre vlak'}

\subsection{Die doel van verkeersveiligheidsopvoeding}

Verkeersveiligheidsopvoeding vorm 'n deel van algemene opvoeding en bou daarop voort, maar met slegs een doel voor oë, naamlik die begeleiding tot verkeersvolwassenheid (Eggink, 1990:57). Soos gestel, kan 'n individu as verkeersvolwasse beskryf word indien hy oor die nodige kennis, vaardighede en 'n positiewe gesindheid beskik om op só 'n wyse deel van die verkeer te wees dat selfbeveiliging en die beveiliging van ander die eerste prioriteit is. Volgens Gregersen en Bjurulf (1996:229) en Du Plooy (1983:42) behels genoemde drie kenmerke die volgende:

- Voldoende kennis van veilige verkeersdeelname wat die onderskeie verkeersreëls en regulasies insluit.

- Voldoende vaardighede om die kennis te kan toepas, ook vir die neem van berekende risiko's.

- 'n Positiewe gesindheid jeens verkeersdeelname en -deelnemers - 'n eienskap wat vergestalt word in hulpvaardigheid, bedagsaamheid en medebetrokkenheid.

- 'n Positiewe gesindheid jeens wetgewing en die -toepassing daarvan. So 'n gesindheid word byvoorbeeld vergestalt in die kweek van positiewe verantwoordelike voetgangers en 'n verantwoordelike (motor-) bestuurstyl.

- Die feit dat waarde geheg word aan die beveiliging van die eie lewe en dié van ander.

- Verantwoordelike optrede in die verkeersituasie wat spreek van respek vir medepadgebruikers.

Met hierdie volwassenheidsbeeld as doel, behoort verkeersveiligheidsopvoeding te fokus op 'n balans tussen kennis, vaardighede, waardes en gesindhede, met laasgenoemde twee, veral, vanuit 'n religieus-kulturele hoek. Tot voor die 1997Grondwet is verkeersveiligheidsopvoeding op twee fronte gehanteer, naamlik as

1 Die sekondêre skoolfase vorm die toepassingsgebied omdat die sekondêre leerling reeds heelwat van die kenmerke van 'n volwassene vertoon. Ook word op hierde fase gekonsentreer vanweë een van die artikelskrywers se betrokkenheid by onderwysersopleiding vir die sekondêre skoolfase. 
algemene verkeersveiligheidsopvoeding, en as gespesialiseerde verkeersveiligheidopvoeding (Dreyer, 1986:11).

\subsection{Algemene verkeersveiligheidsopvoeding: tradisioneel en binne die konteks van Kurrikulum 2005}

Leerders bemeester die tradisionele skoolvakke (soos wat tans nog op sekondêre skoolvlak voorkom) deur middel van 'n sekere voorkennis en denkvaardighede waarmee inligting tot kennis verwerk word of probleme opgelos word. Met herhaalde ervaring ontwikkel die leerder 'n spesifieke gesindheid teenoor sekere vaardighede en/of vakke, wat weer die leerder se motivering om die vakke werklik te bemeester, bemvloed (Woolfolk, 1995:242 e.v.). Daar is dus 'n wisselwerking tussen leervaardighede en die waarde wat aan sodanige vaardighede en kennis geheg word.

Algemene verkeersveiligheidsopvoeding veronderstel die veralgemening van hierdie kennis, kognitiewe vaardighede en gesindhede, wat in die gewone gang van die onderrig-leersituasie bemeester is, na die veld van verkeersveiligheid. Die veronderstelling bestaan dat die kind geleer word om die denkvaardighede wat hy tydens vakonderrig leer, ook in 'n verkeerskonteks te gebruik. Toepaslike denkvaardighede wat tydens vakonderrig gestimuleer word, sluit onder andere die volgende in: om evaluerend op 'n probleemsituasie te reageer (byvoorbeeld die opweeg van risiko's), om self 'n besluit te kan neem en stappe te kan implementeer om 'n probleem op te los. Martinez et al. (1993) se navorsing waarin kennis en vaardighede oor die gebruik van veiligheidsgordels en die invloed van spoed op botsing suksesvol met aspekte van die Natuur- en Skeikunde-kurrikulum geintegreer is, toon dat dit wel doelmatig is - mits doelbewuste beplanning en integrasie geskied! Die vraag is of die gewone SuidAfrikaanse onderwyser wel beplan vir die veralgemening van kennis, vaardighede en gesindhede na verkeersveiligheid, aangesien daar geen blyke van positiewe resultate in terme van die verkeersgedrag van jeugdige padgebruikers gemerk word nie (vergelyk die statistiek in par. 1).

In die lig van 'n sensitiwiteit vir verkeersveiligheidsopvoeding (wat veral tydens onderwysersopleiding gekweek kan word; kyk par. 4), kan algemene verkeersveiligheidsopvoeding wel in die huidige kurrikulums verreken word. In hierdie opsig kan gedink word aan die volgende aspekte wat in vakonderrig betrek kan word:

- Die effek wat alkohol op waarnemingsvermoë het (Biologie).

- Die verlies aan produktiwiteit weens motorongelukke (Ondernemingsbestuur).

- Die verkeerstema en verkeersveiligheidsbewustheid kan effektief tydens die onderrig van kreatiewe skryfwerk bevorder word (Taalonderrig). 
- Reflektiewe denke en besluitneming oor verkeersoptredes kan bevorder word deur verkeersveiligheid as tema in begripstoetse te gebruik (Taalonderrig).

Algemene verkeersveiligheidsopvoeding behoort by uitstek 'n bydrae te lewer tot die vorming van die regte gesindheid en ingesteldheid teenoor verkeersveiligheid, want in die didakties-pedagogiese gebeure behoort die opvoeder onder andere ook leiding aan die opvoedeling te gee in terme van die waardes en norme wat in die gemeenskap bestaan (Du Plooy, 1986:5). Hierdie doelstelling hou dus ook verband met sedelike opvoeding (onder andere die onderskeiding tussen wat reg en verkeerd is) (Vlok, 1987:56). Soos met verkeersveiligheid, geskied hierdie leiding nie by wyse van 'n spesifieke vak nie, maar word veronderstel dat dit die strewe van alle vakke en skoolaktiwiteite behoort te wees. Daarom is dit moontlik en ook nodig om by die voorhou van hierdie morele norme en waardes ook te verwys na verkeersaangeleenthede. 'n Tweede vraag wat dus gevra kan word, is of sodanige veralgemening van waardes, norme, gesindhede en houdings na die terrein van verkeersveiligheid tans in die tipiese skoolklaskamer in SuidAfrika plaasvind.

Uit die uiteensetting van die toekomstige skoolkurrikulum blyk dit dat wat tans onder algemene verkeersveiligheidsopvoeding veronderstel word, in terme van Lewensoriëntering as leerarea verreken word (kyk par. 1 vir 'n uiteensetting van die doelstellings van hierdie leerarea). Spesifieke leeruitkomste (Die Staatskoerant, 1997) wat betrekking het op algemene verkeersveiligheidsopvoeding, sluit die volgende in:

- Om vaardighede te gebruik en houdings en waardes te toon wat verhoudings binne die gesin, groep en gemeenskap kan verbeter.

- Om waardes en respek vir menseregte, soos gereflekteer in ubuntu en ander soortgelyke lewensfilosofieë, te demonstreer.

- Om aangeleerde lewens- en besluitnemingsvaardighede te oefen en beoefen.

- Om die waardes en houdings wat nodig is vir 'n gesonde en gebalanseerde lewenstyl te demonstreer.

Die derde leeruitkoms, naamlik die inoefening van lewens- en besluitnemingsvaardighede, is baie belangrik vir verkeersveiligheid, en word soos volg gemotiveer (Kurrikulum 2005 Gespreksdokument Graad I tot IX, 1997:224):

The development and acquisition of life skills form the essence of life orientation. Leamers have to be equipped with, understand and be able to apply the life skills [ook in die verkeersituasie - MS]. The development of information-gathering strategies should form part of this facet. Life skills per $s e$ are taught and learned, although it is expected from the leamer that he/she will apply [them] on a wider basis, especially in coping with real-life situations 
Dle rol van Christelike waardes en opvoeding in Verkeersvelligheldsopvoeding

[soos verkeersituasies - MS]. The acquisition of knowledge and skills that can balance risk and safety in the individual's experiences [veral van belang by die vermyding van verkeersongelukke - MS], environment and social relationships is crucial to this facet

Inoefening van aangeleerde lewens- en besluitnemingsvaardighede word verder soos volg gekwalifiseer (Kurrikulum 2005 Gespreksdokument Graad I tot IX, 1997:231):

* The ability to take responsibility for oneself and others is demonstrated.

* The responsibility to promote safety awareness, the management of life changes, stress management and conflict resolution (which includes safety issues and practices).

Anders as die huidige skoolkurrikulum, gee Kurrikulum 2005 spesifiek aandag aan waardes, ook insake veiligheidsvraagstukke soos verkeersveiligheid. Die gevolgtrekking waartoe die skrywers van hierdie artikel kom, is dat, alhoewel veronderstel word dat algemene verkeersveiligheidsopvoeding op skool geskied en daar wel geleenthede daarvoor is, sodanige opvoeding en onderrig glad nie tot sy reg kom nie.

\subsection{Gespesialiseerde verkeersveiligheidsopvoeding}

Hoe om as 'n voetganger die pad oor te steek, of 'n motor, motorfiets en 'n fiets te bestuur, vereis die spesifieke gebruik van sekere vaardighede, wat reeds by wyse van algemene verkeersveiligheidsopvoeding bemeester is. Hierdie vaardighede sluit die volgende in. fisiese vaardighede, soos spierbeheer en koördinasie; kognitiewe vaardighede - soos selfstandige besluitneming en probleemoplossing; sosiale vaardighede sodat jy op 'n verantwoordelike wyse met ander padgebruikers kan omgaan; asook affektiewe vaardighede soos om jou emosies te beheer ('n aspek van gesindhede, wat ook aan waardes verwant is) (Theunissen, 1991:22). Volgens Dreyer (1986:7) verwerf die padgebruiker genoemde gespesialiseerde kennis van verkeersveiligheid, verkeersveiligheidsreëls en die vaardighede vir die doelmatige toepassing van die kennis in gespesialiseerde verkeersveiligheidsopvoeding. Die nodige algemene denk-, sosiale en sedelike vaardighede wat nodig is vir verkeersveiligheid behoort dus tydens die aanbieding van die onderskeie vakke soos Wiskunde en Natuur- en Skeikunde onderrig te word. Die inhoud en spesifieke vaardighede van verkeersveiligheidsopvoeding behoort verder ingeoefen te word tydens 'n spesifieke verkeersveiligheidsopvoedingsprogram, soos byvoorbeeld die Skool-bestuursopleidingsprogram.

Hierdie program word spesifiek gemeld aangesien dit die enigste gespesialiseerde verkeersveiligheidsprogram is wat op sekondêre skoolvlak in Suid-Afrika aangebied is (dit is teen die einde van 1996 getermineer weens verskeie eksterne 
faktore, waaronder 'n tekort aan finansiering - mondelinge mededeling deur Van der Merwe, 1997). Tans word dus geen voorsiening gemak vir gespesialiseerde verkeersveiligheidsopvoeding op sekondêre skoolvlak nie. Wanneer gekyk word na die volgende uiteensetting van wat 'n gespesialiseerde motorbestuursopleidingsprogram behels (Gregersen \& Bjurulf, 1996), blyk dit dat die inoefening van geoutomatiseerde kognitiewe en motoriese vaardighede en die vestiging van waardes of houdings deurslaggewend is vir goeie padgebruik. "Goeie padgebruik" word gemeet aan 'n afname in verkeersongelukke op grond van opvoedingsprogramme (Martinez et al., 1993; Sheehan \& Schonfeld, 1992).

Volgens Gregersen en Bjurulf (1996:230) bestaan motorbestuursopleiding uit drie aspekte, naamlik: (i) die aanvanklike leer van nuwe inligting en vaardighede, (ii) die inoefening of ervaring waartydens terugvoer belangrik is vir risiko-evaluering en motivering om verkeersreëls te gehoorsaam, en (iii) selfevaluering van die eie vermoëns in terme van die gedragspatroon wat geopenbaar word. Eksterne faktore wat dié drie aspekte beïnvloed, sluit die volgende in: onderrig, sosiale norme en rolverwagtings (wat kultuurverwant is; kyk par. 2.2) en intrinsieke faktore wat individuele lewenstyl en waardes behels (albei is religieus- en kultuurverwante faktore; par. 2.2), ouderdom, geslag en persoonlikheid. Van genoemde aspekte is die inoefening en verbetering van ervaring in interaksie met ouderdom en ontwikkelingsvlak van wesenlike belang by die voorspelling van ongelukke (Gregersen \& Bjurulf, 1996:231; Cooper et al., 1994). Die inoefening en verbetering van ervaring kan egter slegs effektief wees indien die leerder genoeg waarde heg aan die aktiwiteit.

Motorsbestuursopleidingsprogramme, veral vir beginnerbestuurders van hoërskoolouderdom behoort dus soveel praktiese opleiding as moontlik in te sluit Hierdie voorwaarde is noodsaaklik om die beginnerbestuurder se kognitiewe vaardighede tot 'n vlak van geoutomatiseerdheid te bring en die waarde wat aan die oefening geheg word, positief te kry en te hou.

By die derde fase van opleiding, naamlik selfevaluering van die eie vermoë, toon navorsing (Finn \& Bragg, 1986; Matthews \& Moran, 1986, soos aangehaal deur Gregersen \& Bjurulf, 1996:235; Cooper et al., 1994) dat jonger bestuurders (soos adolessente), en veral dié met min ervaring, nie in staat is om hulle eie bestuursvermoë realisties te evalueer nie en hulle hulleself dus dikwels oorskat. Wanneer hierdie oorskatting by adolessentebestuurders voorkom, hou dit verband met die onbewuste strewe na 'n goeie persepsie van die eie vermoë ten einde 'n positiewe identiteit te bereik (Woolfolk, 1995:70-72; kyk ook Atkinson et al., 1993:730). Vandaar miskien ook die groter voorkoms van motorongelukke wanneer adolessentebestuurders passassiers van dieselfde ouderdomsgroep in die motor het (Cooper et al., 1994:103). Volgens Lehto et al. (1994:197) hou selfevaluering egter ook verband met risiko-evaluering (ook 'n faset van die inoefening van aangeleerde lewens- en besluitnemingsvaardighede soos uiteen- 
gesit vir Lewensoriëntering in Kurrikulum 2005 Gespreksdokument Graad I tot IX, 1997:231). Lehto et al. (1994:197) se navorsing toon dat gedrag, ook motorbestuursgedrag, nie veel verander indien die risiko verbonde aan, byvoorbeeld, bestuur saam met alkoholgebruik, beklemtoon word nie. Genoemde gedrag kan egter beïnloed word indien opvoedingsprogramme meer op die verandering van waardes konsentreer (soos by Lewensoriëntering in Kurrikulum 2005). Dus: as adolessente oortuig kon word dat alkoholgebruik nie die aansien by die portuurgroep verhoog nie, maar eerder verlaag, sou sodanige veranderde waarde 'n positiewe uitwerking op die selfidentiteit, asook motorbestuursgedrag kon hê (Letho et al., 1994). Vanuit 'n Christelike perspektief behoort die bestuurders ook gelei te word om hulle eie lewens en dié van hulle passassiers as waardevol en as 'n gawe van God te sien.

Uit hierdie kursoriese beskrywing van wat 'n enkele gespesialiseerde verkeersveiligheidsopvoedingsprogram behoort te behels, en die invloed daarvan op waardes, is dit duidelik dat die gebrek aan sodanige opvoeding op sekondêre skoolvlak in Suid-Afrika bydraend kan wees tot die hoë voorkoms van verkeersongelukke. Die moontlikheid bestaan dat Kurrikulum 2005 met verloop van tyd 'n verandering teweeg kan bring ten opsigte van genoemde waardes en vaardighede. As dit egter wil slaag, behoort onderwysers tydens hul aanvanklike onderwysersopleiding en indiensopleidingsprogramme onderrig te kry oor die wyse waarop hulle leerders se waardes positief kan beïnvloed.

\section{Onderwysersopleiding in Verkeersveiligheid}

In Suid-Afrika laat die kwaliteit van die verkeersveiligheidsopvoeding wat onderwysers ontvang en die rol wat hulle speel in die verkeersveiligheidsopvoeding van leerlinge veel te wense oor en verskil dit drasties van wat in Eerstewêreldlande geskied. Hoewel verkeersveiligheidsopvoeding nie verpligtend is vir alle onderwysers in lande soos Australië, Brittanje, Finland, Frankryk, Denemarke, Duitsland, Nederland en die Verenigde State van Amerika nie, is dit wel 'n keusevak by die meeste universiteite en kolleges (Du Plooy, 1986:189).

Soos reeds gestel, bied slegs die Potchefstroomse Universiteit vir Christelike Hoër Onderwys in Suid-Afrika verkeersveiligheidsopvoeding as kursus vir onderwysstudente aan. Hierdie toestand is onaanvaarbaar en onverklaarbaar, aangesien alle komitees wat telkens deur die regering aangewys is om die probleem van verkeersveiligheid te ondersoek wel die insluiting van Verkeersveiligheidsopvoedkunde in die professionele opleiding van onderwysers aanbeveel het (Loftus-verslag, 1948; Joubert-verslag, 1958; Du Plessis-verslag, 1964 en die Steyn-verslag, 1972, soos aangehaal deur Marx, 1997). Die hoop kan uitgespreek word dat Kurrikulum 2005 ook 'n verandering teweeg sal bring in die opleiding van onderwysstudente in algemene verkeersveiligheid, maar veral 
in motorbestuursopleiding as faset van gespesialiseerde verkeersveiligheidsopvoeding.

Die dringende noodsaaklikheid vir onderwysers om in te gryp en mee te help aan motorbestuursopleiding, blyk uit die projeksies dat in die jaar 2000 daar waarskynlik 8282819 leerlingbestuurders in die ouderdomsgroep 15-19 jaar sal wees (dit sluit ook motorfietsryers in). Vir die jaar 2005 is die projeksie 9105588 (Van der Westhuizen et al., 1995:13).

\section{Gevolgtrekkings}

Dit is duidelik dat daar geen kitsoplossing vir Suid-Afrika se verkeersveiligheidsvraagstuk bestaan nie. Ander lande het aangetoon dat 'n geleidelike daling in verkeersongelukke teweeggebring kan word deur middel van opvoeding in verkeersveiligheid. Die emstige verkeersveiligheidsvraagstuk van die RSA kan deels opgelos word indien daar geslaag word met die aanbieding van Kurrikulum 2005 se leerarea Lewensoriëntering, waarin ruimte geskep is vir gerigte algemene verkeersveiligheidsopvoeding. Hierdie leerarea word in 1998 egter slegs vir die Grondleggende Fase geïmplementeer en die dividende daarvan vir verkeersveiligheid op alle vlakke van padverkeer sal eers in latere jare sigbaar word.

Onderwysers sowel as leerlinge moet tot die besef van die waarde van verkeersveiligheidsopvoedingsprogramme gebring word. Veral onderwysers moet werklik beplan om verkeersveiligheid in die algemene onderrig van die tradisionele vakke te verreken. Heelwat klem behoort ook geplaas te word op die roeping van die Christen ten opsigte van sy eie en die veiligheid van ander padgebruikers. Verkeersveiligheidsopvoedingsprogramme moet daarom in die konteks van waardestelsels geplaas word om onderwysers en leerders te motiveer om dit te bemeester.

Ten opsigte van gespesialiseerde verkeersveiligheidsopvoeding behoort aandag gegee te word aan die gemelde projeksies vir jong motorbestuurders. Die enigste instelling wat werklik op 'n beplande en sistematiese wyse sodanige opleiding aan groot getalle jong bestuurders kan bied, is die sekondêre skool. Indien die onderwysowerhede erns wil maak met die land se verkeersprobleme moet hulle die nodige fondse en mannekrag beskikbaar stel sodat, eerstens, onderwysers opgelei kan word in verkeersveiligheid en tweedens, adolessente op 'n groot skaal opleiding in die bestuur van motorfietse en motors kan ondergaan.

Indien onderriggewers en leerders die waarde van verkeersveiligheidsopvoedingsprogramme besef, behoort die gemotiveerde aanbieding van sulke programme 'n bydrae te lewer om ons land se hoë botsing- en sterftekoerse te verlaag. 


\section{Bibliografie}

ATKINSON, R.L, ATKINSON, R C , SMITH, E.E. \& BEM, D J. 1993. Introduction to Psychology 11 de uitgawe. Orlando : Harcourt Brace \& Company.

COOPER, P J, PINLI, M. \& CHEN, W. 1994 An examination of the crash involvement rates of novice drivers aged 16-55 Accident Analysis and Prevention, 27(1) 89-104

DE BRUYN, P J 1992. Die Christen en die verkeer - 'n lig op die pad Die Kerkblad, 95(2891):7-8

DE BRUYN, P J 1993. Die Tien Gebooie. Midrand : Varia

DREYER, LA. 1986. Die opvoedings- en opleidingstaak van die Nasionale Verkeersveiligheidsraad Potchefstroom : PU vir CHO. (D.Ed -proefskrif)

DU PLOOY, H.G. 1983. Verkeersveiligheid: 'n handleiding vir onderwysers sekondêr NVVR : Pretoria

DU PLOOY, H.G. 1986. Die opvoeding en onderrig van verkeersveiligheid in skoolverband Pretoria : UNISA (D Ed -proefskrif.)

EGGINK, $\mathbf{R}$ 1990. Die wetenskapsteoretiese grondslae van die verkeersveiligheidsopvoedkunde Potchefstroom : PU vir CHO (M.Ed.-verhandeling.)

FOWLER, S., VAN BRUMMELEN, H.W. \& VAN DYK, J. 1990. Christian schooling Education for freedom Potchefstroom : Potchefstroom University for CHE

GARCIA, E. 1994. Understanding and meeting the challenge of student cultural diversity Boston : Houghton Mifflin Company

GREGERSEN, N.P. \& BJURULF, P 1996 Young drivers: Towards a model of their accident involvement Accident Analysis and Prevention, 28(2):229-241

HAT

kyk

ODENDAL, F.F., red

KURRIKULUM 2005 GESPREKSDOKUMENT GRAAD I TOT IX. 1997. (Uitgestuur deur die Departement van Onderwys insake uitkomsgebaseerde onderrig ) April

LEHTO, M R., JAMES, D.S \& FOLEY, J P 1994 Exploratory factor analysis of adolescent attitudes toward alcohol and risk. Journal of Safety Research, 25(4):197-213

MARTINEZ, R, MARTIN, R., LEVTNE, D \& ALTMAN, D. 1993. Effect of injury control information integrated into a high school physics curriculum. (Paper presented at the 37th annual conference of the Association for the Advancement of Automobile Medicine, in San Antonio, Texas.)

MARX, O. 1997. Die rol van waardes, as komponent van motivering, in verkeersveiligheidsprogramme vir onderwysstudente, Potchefstroom : PU vir CHO (M.Ed-verhandeling)

ODENDAL, F.F., red. 1994. Verklarende handwoordeboek van die Afrikaanse Taal Midrand : Perskor.

OOSTHUIZEN, I.J., BOTHA, P., BRAY, W, MARAIS, D., MENTZ, P.J., OOSTHUIZEN, L., VAN DER WESTHUIZEN, P C \& VAN SCHALKWYK, O J 1994. Onderwysregsapekte vir onderwysbestuur Pretoria : Van Schaik

POSTMA, F. 1987 Die invloed van kultuur op adolessensie. (In Monteith, J.L. de K. Postma, F. \& Scott, M. Die opvoeding en ontwikkeling van die adolessent. Potchefstroom : PU vir CHO. p. 215-235.)

SCOTT, M. 1987. Sedelike ontwikkeling. (In Monteith, J.L de K., Postma, F. \& Scott, M Die opvoeding en ontwikkeling van die adolessent. Potchefstroom : PU vir CHO p 15I-180.)

SCOTT, M. 1991. Goals, attributions and self-efficacy as related to course choice and academic achievement of first-year university students Potchefstroom : PU vir CHO (D Ed.-proefskrif.) 
SENTRALE STATISTIEKDIENS

kyk

SUID-AFRIKA Sentrale Statistiekdiens

SHEEHAN, M \& SCHONFELD, C 1992. Changes in young Australians' drunk driving between 1988-1991: Maturation or social change? (Paper presented at the 12th World Congress of the International Association for Accident and Traffic Medicine and 7th Nordic Congress on Traffic Medicine held at Helsinki, Finland.)

SMIT, S.J. 1990. Ry veilig met 'n ander houding. Robot, 1:28-29, Jan

SMIT, S.J. \& DRINKWATER, M. 1989. 'n Ondersoek na die ontwerp van 'n kurrikulum vir verkeersveiligheidsopvoedkunde vir die opleiding van onderwysstudente en onderwysers Potchefstroom : PU vir CHO

STAATSKOERANT

kyk SUID-AFRIKA. Staatskoerant

STEYN, H.J. 1987. 'n Perspektiwiese oorsig van verkeersveiligheidsopvoeding. (In Simposium oor verkeersveiligheidsopvoeding in die formele en nie-formele onderwys Aangebied deur die Nasionale Verkeersveiligheidsraad op 29 en 30 September 1987 te Pretoria. p. 200-224.)

SUID-AFRIKA Sentrale Statistiekdiens. 1994. Padverkeersbotsings. (Verslag No. 71-6101/1990.) Pretoria : Staatsdrukkery.

SUID-AFRIKA 1997. Staatskoerant. 384:18051, Jun. 6.

TAUTE, W 1985. 'n Ondersoek na die persoonlike betrokkenheid van die jeugdige by die verkeersveiligheidsituasie. Pretoria : UNISA. (D Ed.-proefskrif)

TAUTE, W 1987. Opleiding van onderwysers en onderwysstudente in verkeersveiligheidsopvoeding. (In Simposium oor verkeersveiligheidsopvoeding in die formele en nie-formele onderwys. Aangebied deur die Nasionale Verkeersveiligheidsraad op 29 en 30 September te Pretoria. p. 1-9.)

THEUNISSEN, H.M 1991. Verkeersveiligheidsopvoedkunde: 'n handleiding vir studente in verkeersveiligheidsopvoedkunde. Potchefstroom : PU vir $\mathrm{CHO}$

VAN DER MERWE, E. 1997. Mondelinge mededeling insake die opskorting van gespesialiseerde verkeersveiligheidsprogramme op sekondêre skoolvlak. Potchefstroom : Sentrum vir Verkeersveiligheidsopvoeding

VAN DER WALT, B.J 1997 Being human in a Christian perspective Series F2: Brochures of the Institute for Reformational Studies, nr. 68. Potchefstroom : Potchefstroomse Universiteit vir Christelike Hoër Onderwys.

VAN DER WALT, J.L. 1984. Grondslae van 'n sentrum/buro/departement vir verkeersveiligheidsopvoeding in die RSA. (In Ondersoek na die wenslikheid van 'n instelling vir verkeersveiligheidsopvoeding in die RSA. Potchefstroom : PU vir $\mathrm{CHO}$ p. 1-25.)

VAN DER WESTHUIZEN, P C., STEYN, H.J., VREKEN, N.J., BOSHOFF, C H., VAN RENSBURG, L.R.J \& DE BRUYN, S.C. 1995 Bestuursplan vir bestuurderopleiding Projekverslag aan die Departement van Vervoer. Potchefstroom : Potchefstroomse Universiteit vir Christelike Hoër Onderwys.

VAN RENSBURG, C.J J., LANDMAN, W.A. \& BODENSTEIN, H.C.A. 1994 Basiese begrippe in die Opvoedkunde 6 de uitgawe. Halfway House : Orion.

VLOK, M. 1987. Ouer-en-kindprogram. (In Simposium oor verkeersveiligheidsopvoeding in die formele en nie-formele onderwys. Aangebied deur die Nasionale Verkeersveiligheidsraad op 29 en 30 September 1987 te Pretoria p. 53-61.)

WOOLFOLK, A.E. 1995. Educational Psychology 6e uitgawe Boston : Allyn \& Bacon 